\title{
The myth of encroachment
}

\author{
Ann Brower
}

\author{
Correspondence: Ann.Brower@ \\ lincoln.ac.nz \\ Faculty of Environment, Society and \\ Design, Lincoln University 7647, 810 \\ Forbes Building, P O Box 84, \\ Christchurch, New Zealand
}

\begin{abstract}
Scholars of pastoralism often refer to changes of pastoral land tenure as 'encroachment.' The New Zealand case of pastoral land tenure reform suggests that this is incorrect for several reasons. First it takes the point of view of the pastoralist, which introduces unnecessary bias. Second, it assumes that all changes in land tenure are situations in which the state, or another powerful agent, takes land away from the less powerful pastoralists. Third, it assumes a single immutable power relation between the state (or other external actor initiating land tenure reform) and the pastoralist in which the state is more powerful and is only too happy to exercise its power whilst expropriating the pastoralists of the land they use. The term 'encroachment' implies that there is just one pattern of land tenure change. I suggest that land tenure reform is a more apt, less biased, descriptor.

Keywords: New Zealand, Pastoral leases, Land reform, Economics
\end{abstract}

\section{Findings}

Scholars of pastoralism often refer to changes of pastoral land tenure as 'encroachment' (Degang et al. 2010; Salzman 1994; Benjaminsen 2009; Adriansen 1999; Weaver 1996). To encroach is to intrude on someone else's territory or impinge on someone's right to something, such as privacy. In this article, I use the New Zealand case of pastoral land tenure reform as evidence that 'encroachment' is incorrect as a global descriptor for several reasons. First it takes the point of view of the pastoralist, which introduces unnecessary bias. Second, and more grievously, it assumes that all changes in land tenure are situations in which the state, or another powerful agent, takes land away from the less powerful pastoralists. This assumes that there can be no land tenure changes in which the state gives land to the pastoralists. Further, it assumes a single immutable power relation between the state (or other external actor initiating land tenure reform) and the pastoralist in which the state is more powerful and is only too happy to exercise its power whilst expropriating the pastoralists of the land they use.

The term 'encroachment' implies that there is just one pattern, or narrative, of land tenure change. The trouble with such a universalist thesis is that it takes just one counter-example to deflate it. I contend that modern-day New Zealand is the deflationary counter-example. I therefore suggest that land tenure reform is a more apt, less biased, descriptor.

\section{Springer}

(C) 2012 Brower; licensee Springer. This is an Open Access article distributed under the terms of the Creative Commons Attribution License (http://creativecommons.org/licenses/by/2.0), which permits unrestricted use, distribution, and reproduction in any medium, provided the original work is properly cited. 


\section{Land reform in New Zealand's South Island high country}

Geographically, the 'high country' of New Zealand's South Island comprises the eastern slope of the Southern Alps, the main divide that forms the backbone of the South Island. From 1856 to 1992, the high country enjoyed a stable mix of land tenure that, to start, made pastoralism viable in the harshly beautiful landscapes. From 1856 to 1992, the Crown (later to become the New Zealand (NZ) government) owned 2.4 million $^{\text {a }}$ ha of South Island high country land. For 150 years and under several successive land acts, the Crown leased land to runholders ' 'for pastoral purposes only' (Land Act 1948 s.51 (1)(d)). Under pastoral leases, runholders' property rights were strong - 33-year perpetually renewable terms - but narrow - no subdivision, no golf courses, and no soil disturbance (Brower 2008).

In 1992, the Minister of Lands and of Conservation embarked on a land tenure reform to 'divvy up' the high country. Land with value for biodiversity, landscape, or recreation could become public conservation land as parks or reserves. And land 'capable of economic use' could be privatised. However if we take prevalence of articles in major newspapers as an indicator of public awareness, ${ }^{c}$ the general public in New Zealand knew little of the policy until 2006.

\section{Landscape transformation, financial gains, and bargaining skill}

On the ground, tenure review in New Zealand has often resulted in land above 1,000 m altitude becoming public conservation land administered by the Department of Conservation, while productive land along river valleys and lakeshores has been converted to freehold (in some countries called fee-simple title) and opened to development. This conversion to freehold (hereinafter privatisation) has allowed for much of the new viticulture near the resort town of Queenstown, residential subdivisions along Lakes Wakatipu and Wanaka, and the 'for sale' signs that sprinkle the Central Otago hills (Brower 2008, Brower et al. 2010, 2011).

The privatisation is also instigating a landscape transformation. Land that had been in 80 Crown pastoral leases, with an average size of 5,938 ha and where land use was restricted to extensive sheep grazing, has so far been subdivided into at least 865 parcels, of which 550 are smaller than 50 ha. These 865 parcels are now freehold, and open to development (Swaffield and Brower 2009). To date, $20 \%$ of these parcels have been sold by at least 28 of the new landowners. Those who have sold some or all of their new freehold land have grossed NZ\$135.7 million ${ }^{\mathrm{d}}$ (Brower et al. 2011).

To put this in context, those 28 new owners who have sold land since privatisation initially bought freehold title to 101,752 ha from the Crown for NZ\$6.9 million. They have subdivided and/or sold 47,110 ha (46 \%) of their new freehold land for $\$ 135.7$ million. Table 1 gives the details. If we consider the ratio between land purchase price (to buy freehold title from the Crown) to land selling price (to sell freehold land on the open and global market) as an indicator of financial gains realised by pastoralists, the results in column 7 (Table 1) suggest the pastoralists have enjoyed financial gain in the aftermath of land tenure reform. When the results are broken down further, by parcel on-sold rather than by former leasehold as displayed in Table 1, the financial gains to the pastoralists are more striking. The ratio of purchase price to on-selling price varies from 2 to 27,096, with a median value of 992. Thus, pastoralists are selling land 
Table 1 Land sales prices: for freehold title to former pastoral lease land, and for freehold land after privatisation ${ }^{a}$

\begin{tabular}{|c|c|c|c|c|c|c|}
\hline $\begin{array}{l}\text { Name of former } \\
\text { leasehold }\end{array}$ & $\begin{array}{l}\text { Privatised } \\
\text { hectares } \\
\text { (A) }\end{array}$ & $\begin{array}{l}\text { Total paid for } \\
\text { freehold } \\
\text { (B) }\end{array}$ & $\begin{array}{l}\text { On-sold } \\
\text { hectares } \\
\text { (C) }\end{array}$ & $\begin{array}{l}\text { Total paid for on-sold } \\
\text { land } \\
\text { (D) }\end{array}$ & $\begin{array}{l}\text { Number } \\
\text { of } \\
\text { on-sold } \\
\text { parcels }\end{array}$ & $\frac{(D) /(C)}{(B) /(A)}$ \\
\hline Alphaburn & 3365 & $\$ 267,500$ & 193 & $\$ 10,100,000$ & 1 & 658 \\
\hline Bendigo & 8727 & $\$ 172,500$ & 625 & $\$ 4,685,000$ & 13 & 379 \\
\hline Closeburn & 930 & $\$ 199,889$ & 14 & $\$ 17,696,000$ & 25 & 6090 \\
\hline Cone Peak & 2181 & $\$ 350,000$ & 40 & $\$ 1,650,000$ & 1 & 257 \\
\hline Eastburn Waitiri & 5910 & $\$ 535,000$ & 1810 & $\$ 9,700,000$ & 2 & 59 \\
\hline Glenroy & 1973 & $\$ 400,000$ & 13 & $\$ 425,400$ & 3 & 159 \\
\hline Hillend & 2659 & $\$ 336,000$ & 2443 & $\$ 26,200,000$ & 2 & 85 \\
\hline $\begin{array}{l}\text { Midrun-Lake } \\
\text { McKay }\end{array}$ & 5372 & $\$ 179,375$ & 1 & $\$ 492,000$ & 7 & 11,788 \\
\hline Mt Pisa I \& II & 4633 & $\$ 413,000$ & 53 & $\$ 2,066,000$ & 5 & 435 \\
\hline Mt Rosa & 1388 & $\$ 155,556$ & 53 & $\$ 7,521,000$ & 21 & 1265 \\
\hline Pukaki Downs & 3722 & $\$ 191,000$ & 582 & $\$ 4,665,000$ & 4 & 156 \\
\hline $\begin{array}{l}\text { Queensberry } \\
\text { Hills }\end{array}$ & 2905 & $\$ 120,000$ & 179 & $\$ 7,347,500$ & 20 & 99 \\
\hline $\begin{array}{l}\text { Rhoboro } \\
\text { Downs }\end{array}$ & 4648 & $\$ 55,000$ & 127 & $\$ 1,900,000$ & 1 & 1264 \\
\hline Spotts Creek & 3344 & $\$ 282,600$ & 3306 & $\$ 2,030,000$ & 1 & 7 \\
\hline Waiorau & 2691 & $\$ 191,000$ & 4 & $\$ 785,000$ & 1 & 2765 \\
\hline Wentworth & 3840 & $\$ 351,111$ & 3441 & $\$ 5,547,000$ & 14 & 18 \\
\hline Woodbine & 338 & $\$ 110,000$ & 0.1 & $\$ 100,000$ & 1 & 3069 \\
\hline Ardgour & 3719 & $\$ 640,000$ & 229 & $\$ 1,466,000$ & 6 & 37 \\
\hline Avalon & 1352 & $\$ 134,000$ & 1341 & $\$ 2,264,000$ & 1 & 17 \\
\hline Ben Ohau & 4375 & $\$ 169,500$ & 3695 & $\$ 6,047,000$ & 9 & 42 \\
\hline Blackstone Hill & 2684 & $\$ 175,000$ & 1055 & $\$ 129,000$ & 1 & 2 \\
\hline Brookdale & 1027 & $\$ 106,000$ & 1030 & $\$ 2,000,000$ & 1 & 19 \\
\hline Cairnmuir & 4437 & $\$ 141,000$ & 4082 & $\$ 5,334,000$ & 13 & 41 \\
\hline Earnscleugh & 16,410 & $\$ 608,889$ & 15,273 & $\$ 1,624,000$ & 7 & 3 \\
\hline $\begin{array}{l}\text { Glencreagh- } \\
\text { Camberleigh }\end{array}$ & 922 & $\$ 310,000$ & 922 & $\$ 1,751,000$ & 2 & 6 \\
\hline Halwyn & 3713 & $\$ 124,444$ & 623 & $\$ 1,397,500$ & 7 & 67 \\
\hline Mataura Valley & 4322 & $\$ 164,858$ & 4357 & $\$ 9,000,000$ & 1 & 54 \\
\hline $\begin{array}{l}\text { Omahau } \\
\text { Downs }\end{array}$ & 165 & $\$ 31,000$ & 6 & $\$ 1,819,000$ & 8 & 1697 \\
\hline Totals & 101,752 & $\$ 6,914,222$ & 47,110 & $\$ 135,741,400$ & 178 & \\
\hline
\end{tabular}

${ }^{a}$ Leasehold includes a lake view or lies within $10 \mathrm{~km}$ of Queenstown or Wanaka. ${ }^{b}$ Leasehold neither includes a lake view nor lies within $10 \mathrm{~km}$ of Queenstown or Wanaka.

Adapted from Brower et al. 2011.

between 2 and 27,096 times the price at which they purchased the freehold (Brower et al. 2011).

Financial gains for pastoralists are not, by themselves, an indication of bad land policy. Pastoralists' financial gains after privatisation might properly be explained as a public good, as higher land prices and productivity generate economic growth and tax revenue. What is less easy to explain, and what again violates the presumptions of the encroachment 
narrative, is that, the Crown paid more to runholders to purchase leasehold rights of 235,000 ha than the runholders paid the Crown for freehold rights of 290,000 ha.

From 1992 through 2008, the Crown bought pastoral rights to about 235,456 ha, and the runholders bought titles to about 278,897 ha. In terms of option values and property rights, the Crown bought the option to graze sheep, or to exclude sheep from, of about 235,000 ha. The runholders bought the options to subdivide and develop about 290,000 ha beyond its pastoral uses (Brower et al. 2011). On the face of it, it seems that what the Crown sold the option to develop land - would be more valuable than what it bought - the option to graze the unforgiving, high altitude country deemed incapable of other economic use. Yet the Crown paid runholders NZ\$22,682,991 more for the grazing option than runholders paid the Crown for the development option (Brower et al. 2010).

Further exploration of the inner workings of land reform negotiations shed light on the outcomes and the underlying power relations. In each deal, rather than taking an active stance in land reform negotiations, mid-level bureaucrats directed the government contractors making deals to be neutral in negotiations. The trouble is that the Crown and its taxpayers have a sizeable financial interest in the high country; and the Crown's failure to advocate for that interest was a tacit agreement to forfeit its, and the public's, rights from the start (Brower 2006, 2008).

More to the point, analysis of individual prices paid revealed that the runholders who received freehold title to the most land also got the most favourable per hectare price; that is, those who kept the least land got the worst price per hectare, and those who kept the most land got the best price per hectare. This means that while privatising high country land, the Crown was giving a bulk discount - the more land it privatised, the less it charged per hectare. A bulk discount is a manifestation of an economic demand curve. Thus, the prices agreed to in negotiation closely resemble the runholders' demand curve for freehold land. In other words, the Crown paid whatever it took to close land reform deals (Brower et al. 2010). Again, this is inconsistent with the assumptions of the encroachment narrative.

\section{Conclusion}

Both the financial gains to pastoralists after privatisation and the pattern of generous payments to pastoralists during the land tenure reform process point to an underlying power dynamic that is very different from that suggested by the encroachment narrative. Encroachment implies that the state is more powerful and is readily willing to exercise that power over the subservient pastoralists. However, it is not so in New Zealand where pastoralists use skillful bargaining to their financial advantage. Further, the Crown's consistent under-valuing of the development options it is selling suggests that it is pathologically unwilling or politically unable to exercise its power on its side of the land reform negotiation table. Thus, New Zealand pastoral land reform indeed appears to debunk the encroachment narrative.

\section{Endnotes}

${ }^{a}$ For comparison, Israel is 2 million ha, and Belgium is about 2.5 million ha.

bIn New Zealand, a 'runholder' is a pastoralist who holds a Crown pastoral lease, also known as a high country farmer, leaseholder, or lessee. 
${ }^{c}$ From 1992 to 2006, the two major daily newspapers on the South Island carried 80 and 124 articles, editorials, and letters to the editor respectively. On average, that is 6.2 articles/year for The Press (Christchurch) and 9.5 articles/year for the Otago Daily Times (Dunedin). For reference, in 2005, The Press ran 14 articles in 7 weeks about a proposed tour for the Black Caps, the national cricket team.

${ }^{\mathrm{d}}$ In 2012, the NZ dollar hovers around US $\$ 0.80$.

Competing interest

The author declare that she has no competing interests.

Author's information

$A B$ is a senior lecturer on Public Policy, Faculty of Environment, Society and Design, Lincoln University, Christchurch, New Zealand

Received: 18 January 2012 Accepted: 16 March 2012

Published: 9 May 2012

References

Adriansen, H.-K. 1999. Pastoral mobility as a response to climate variability in African drylands. Geografisk Tidsskrift, Danish J Geogr 1: 1-10.

Benjaminsen, T.A., and B. Ba. 2009. Farmer-herder conflicts, pastoral marginalisation and corruption: a case study from the inland Niger delta of Mali. Geogr J 175(1): 71-81. doi:10.1111/j.1475-4959.2008.00312.x.

Brower, A. 2006. Interest groups, vested Interests, and the myth of apolitical administration - the politics of land tenure reform on the South Island of New Zealand. Wellingon: Fulbright New Zealand.

Brower, A. 2008. Who owns the high country? Nelson: Craig Potton Publishing.

Brower A, Meguire P, and DeParte A. 2011. Does tenure review in New Zealand's South Island give rise to rents? New Zealand Economic Papers. in press. Available online 14 September 2011, at http://dx.doi.org/10.1080/ 00779954.2011.608247.

Brower, A., P. Meguire, and A. Monks. 2010. Closing the deal: principals, agents, and subagents in New Zealand land reform. Land Economics 86(3): 467-492.

Degang Z, Jizhou R, Limin H and Squires V. 2010. Agro-Pastoral Integration in NW China: A New Paradigm? Towards Sustainable Use of Rangelands in North-West China (No. 978-90-481-9622-7): Springer Netherlands. Retrieved from http://dx.doi.org/10.1007/978-90-481-9622-7_9

Salzman, P.C. 1994. Afterword: reflections on the pastoral land crisis. Nomadic Peoples 34(35): 159-163.

Swaffield, S and Brower, A. 2009. Globalisation, contest and paradox in a continuing cultural landscape: Land reform in the New Zealand High Country. Geografisk Tidsskrift, Danish Journal of Geography, 109(2):161-179

Weaver, J.C. 1996. Beyond the fatal shore: pastoral squatting and the occupation of Australia, 1826 to 1852. Am Hist Rev 101(4): 981-1007.

doi:10.1186/2041-7136-2-3

Cite this article as: Brower: The myth of encroachment. Pastoralism: Research, Policy and Practice 2012 2:3.

\section{Submit your manuscript to a SpringerOpen ${ }^{\circ}$ journal and benefit from:}

- Convenient online submission

- Rigorous peer review

- Immediate publication on acceptance

- Open access: articles freely available online

- High visibility within the field

- Retaining the copyright to your article

Submit your next manuscript at $>$ springeropen.com 